\title{
QFD for the Motorcycle Service Quality Analysis and Improving Customer Satisfaction
}

\author{
Arvindakarthik K S $\mathbf{S}^{1}$, Mohan Kumar K K $\mathbf{K}^{2}$, Gokul Sangar E \\ ${ }^{1,2,3}$ Department of Aeronautical Engineering, Sri Ramakrishna Engineering College, Coimbatore-641030, Tamil Nadu, India
}

\begin{abstract}
In the Total Quality Management (TQM) where quality function deployment (QFD) is used for converting customer's language into technical language and it is the important tool for customer's satisfaction. The effect of servicing performances which satisfaction a user is known as service quality. The resource and time allocation are wasted in service development because of the lack of proper estimation service quality attributes. The QFD attributes are customers needs, technical requirements, Correlation matrix, Ranking of customer's language, Relationship matrix and Ranking of technical language. To identification the weak attributes are achieved through analysis of data which helps the organisation to measure their performance and accelerate the development of innovative services which are crucial to customers.
\end{abstract}

Keywords: Total Quality Management (TQM), Quality Function Deployment (QFD), Service quality analysis, Customer Satisfaction.

\section{Introduction}

The subject of service quality has aroused considerable recent interest among business people and academics. Of course, Motorcycle buyers have always been concerned with quality, but the increasing competitive market for many services has led consumers to become more selective in the services they choose. Conceptualizing the quality for services is more complex than for goods.

A service is an act or performance offered by one party to another. In this competitive era, for any organization such as Motorcycle service industries it is necessary to provide quality service to retain their customers ${ }^{e e}$. Service quality has major influence on customer satisfaction as customers buy products or services and on whether they continue to do so. With the aim of sustaining long term relationships with their customers, many businesses have changed their strategic focus to emphasize customer retention. Preserving their long term customer relationships requires that these businesses both measure and appropriately adjust the quality of their customer"s service.

Quality is an extremely difficult concept to define in a few words. At its most basic, quality has been defined as conforming to requirements. This implies that organizations must establish requirements and specifications; once established, the quality goal of the various function of an organization is to comply strictly with these specifications. Many analyses of service quality have attempted to distinguish between objective measures of quality and measures which are based on the more subjective perceptions of customers. Due to the absence of tangible manifestations, measuring service quality can be difficult but there are possible research approaches... It is not sufficient for companies to set quality standards in accordance with misguided assumptions of customers ${ }^{\text {ee }}$ expectations.

A further problem in defining service quality lies in the importance which customers often attach to the quality if the service provider is distinct from its service offers - the two cannot be separated as readily as in case of goods Because of the intangible characteristics of service, the measurement and evaluation is quite difficult. Also there exists a nonlinear relationship between the customer satisfaction and the perception of the service. Being this is the scenario; a country like India who has a major GDP share from the service firms, the service quality issues should be well addressed. The Kano Model of Customer (Consumer) Satisfaction classifies product attributes based on how they are perceived by customers and their effect on customer satisfaction. These classifications are useful for guiding design decisions in that they indicate when good is good enough, and when more is better. The Kano Model of Customer satisfaction (Figure 1) divides product attributes into three categories: threshold, performance, and excitement. A competitive product meets basic attributes, maximizes performances attributes, and includes as many "excitement" attributes as possible at a cost the market can bear.

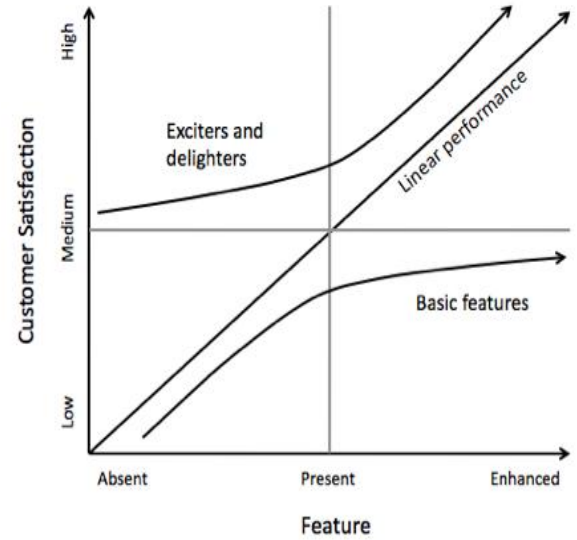

Figure 1

The origin of QFD is traced to the quality tables that were developed in Kobo Shipyard, Japan in the year 1960. The formal appearance of QFD as the TQM technique was made possible through the works of Yoji Akao in the year 1972 (Akao and Mazur, 2003). Thereafter, the popularity of QFD spread across the world. Also, a large number of case studies reporting QFD's successful implementation and its benefits appeared in literature (Chan and $\mathrm{Wu}, 2002$ ). A few researchers have brought out different definitions (Zairi and 


\section{International Journal of Science and Research (IJSR) \\ ISSN (Online): 2319-7064 \\ Index Copernicus Value (2013): 6.14 | Impact Factor (2014): 5.611}

Youssef, 1995), leading to the proposition that QFD is a technique used for converting customers ${ }^{\text {ee }}$ vague languages into technical languages. Therefore QFD facilitates deployment of customers ${ }^{\text {ee }}$ voices in the practising environment.

In this era of increasing competition, QFD is supposed to reveal the hidden and open voices of customers and support the organizational managers in meeting market requirements. The implementation of QFD progresses through the development of a composite matrix known as House of Quality (HOQ). The conceptual features of HOQ are shown in Figure 1. As shown, HOQ consists of six main sub matrices (Kumar and Midha, 2001; Han et al., 2001). The construction of HOQ begins by developing a customer language matrix, whose inputs are vague customer voices. Consequently, the second matrix titled, ranking of customer languages ${ }^{e c}$ is developed. The values indicating the ranks of the customer languages are determined by considering the competitors $^{\text {ee }}$ performance and companies ${ }^{\text {ee }}$ affordability in fulfilling the customer languages. The third matrix, consisting of the technical languages corresponding to the customer languages, is developed. The fourth matrix is constructed by entering values to represent the degree of relationships between customers and technical languages. The fifth matrix, consisting of values representing the ranking of technical languages, is then formed. The sixth and last major sub matrix of HOQ is the correlation matrix, which is constructed by entering the values to represent the correlation among the technical languages. All the matrices developed are joined to construct HOQ.

The construction of HOQ requires the involvement of personnel with adequate theoretical and practical knowledge about the customers ${ }^{\text {ee }}$ voices that are under consideration. Following the development of $\mathrm{HOQ}$, the engineers and production managers are required to study the completed QFD's contents and develop target values and process plans. Thus the customer voices are translated into technical languages through the development of HOQ, which penetrates into the field of practice. Initially, QFD was used as a product development (Lockamy and Khurana, 1995) technique. However, during recent times, it has proven to be a feasible technique for several applications where customer voices are required to be translated into technical languages (Chan and Wu, 2002; Sahney et al., 2003; Sahney et al., 2004).

\section{Case Study}

In order to examine the aspects of QFD in a service Quality, a case study was carried out in a maintenance intensive Motorcycle service station. The present study focuses on the measurement of current service quality of a typical motorcycle dealership in an Indian city. The main objectives of the present study are to test the reliability of the developed data and to develop, propose a QFD for service quality improvement. Here the investigator administered QFD from a sample of 71 customers in motorcycle service industry, i.e. a representative survey of respondents, owners of one of the Branded vehicles.

The reliability of tools was checked using Cronbach"s alpha method and there by standardized. QFD process utilizes a set of matrix diagrams which are related to one another. The QFD matrix (house of quality) is the basis for all future matrices needed for the QFD method. The number of matrices is depends on the scope of the project. The process continues until each objective is refined to an actionable level (Besterticld, 2006). But researchers give priority to the initial house of quality matrices (Park and Kirn, 1998; Tan and Pawitra, 2001, 2003: Min and Kirn. 2008; Birdogan et a/, 2009), through this matrix; action plans are developed to improve the service quality. Identifying basic customer needs named "What "s" constitutes the starting point of the HoQ and stand on the left of the house. It follows defining the customer priority level of these needs by translating them into numeric values.

\section{The Priority Levels For Customer Needs}

As stated in the conceptual background, defining customer needs constitutes the first step of the QFD model (Matzler and Hintehubcr, 1998). In the process of defining importance, the 71 respondents were asked to mark the importance of attributes according to a five point Likert scale. The left extreme of the scale is marked as least important and the right extreme as the most important (Besterfield, 2006). The scale reliability analysis was conducted. The Cronbach's alpha value was got as 0.991 , which is in an acceptable level (De Vellis, 1991). An arithmetic mean score for every service attributes was computed. The results implied that the most important service quality attribute in the category is the error free vehicle service, followed by vehicle - delivery at the promised time, providing fast services, willingness of staffs to help throughout and enough number of staff. The priority levels for Customer Needs are,

a) On time delivery

b) Charge fairness

c) Accident Repair Roadside assistance

d) After service cleanliness

e) Handover timing

f) Schedule flexibility

g) Comfort in waiting area

h) Friendliness of service advisor

i) Explanations of service advisor

j) Responsiveness of service advisor

k) Rectification

1) Arranging service visit

m) Cleanliness of service station

\section{The Technical Requirements}

After defining customer needs and priority levels, technical requirements are defined by the QFD team. The QFD team involves five service managers, two general managers, one customer relation manager and the researcher Error tree vehicle servicing and no-delay in delivery are found to be the critical faaoi affecting customers ${ }^{\text {ee }}$ satisfaction. The major reasons responsible for delay in delivery are the following.

a) Delay at spare parts counter.

b)Delay at washing station.

c) Delay due to overloading at technical repair station.

\section{Volume 4 Issue 11, November 2015}




\section{International Journal of Science and Research (IJSR) \\ ISSN (Online): 2319-7064}

Index Copernicus Value (2013): 6.14 | Impact Factor (2014): 5.611

The QFD process identified the need of "express service and two-tech bay", "pick and drop" facility, "post service follow up" (PSF), "on road services" (OS), enough parking space, work completion-status monitoring, single window service, proper scheduling for washing and technical repair etc. Finally, eighteen technical requirements were scrutinized. The technical design requirements are

a) Improve the recourses

b) Open on weekends

c) Regular Audit by Manager

d) Modern Equipment's

e) Trained service advisors

f) Offering road test to customer

g) Online service booking

h) Availability of Spare Parts

i) Provide Maintenance Tips

j) well trained field technicians

k) Pre Assigning of service advisor

1) Periodic servicing

m) Washing \& final check up

n) Pricing policy

o) Soft skill behavioural training

p) Pre entering of vehicle details

q) Fixed cleaning schedule

r) Entertainment facilities

\section{The Performance Score And Constituting the Relationship Matrix}

Thus, the choice of a relationship rating scheme is critical in QFD applications. The study of Park and Kirn (1998) revealed thai most of the QFD works used a Rating scale of 1-3-9 format, Other scales are 1-3-5, 1-5-9, 1-2-4, and 1-6-9 (Park and Kirn, 1998). None of the applications provided an explicit justification for the choice of such a rating scale."There is no scientific basis for any of the choices" added Cohen (1995). Being the fact that a rating scale of 1-39 is used by most of the researchers (Park and Kirn, 1998), this work is also adopting a 1-3-9 rating scale. In this matrix, 1 shows weak relation while "3" implies medium relation and ' 9 " implies strong relation; An empty cell in the matrix implies that there is no relationship between the customer need and technical requirement.

The survey of five service managers conducted for completing the matrix. The relationship level between customer needs and technical requirements can be seen in HOQ table. Determining the target value of design requirement is a complicated process because of the complexity in quantification (Iranmanesh, 2008). The current work follows the method listed out by Besterfield (2006). In creating target values, first of all technical requirements are evaluated based on current performance. The current technical performance is evaluated in a 5 point scale (1for very low performance and 5 for very high performance) by the service manager. A target value for each technical descriptor is included in the HOQ matrix. This is an objective measure that defines values that must be obtained to achieve the technical descriptor.

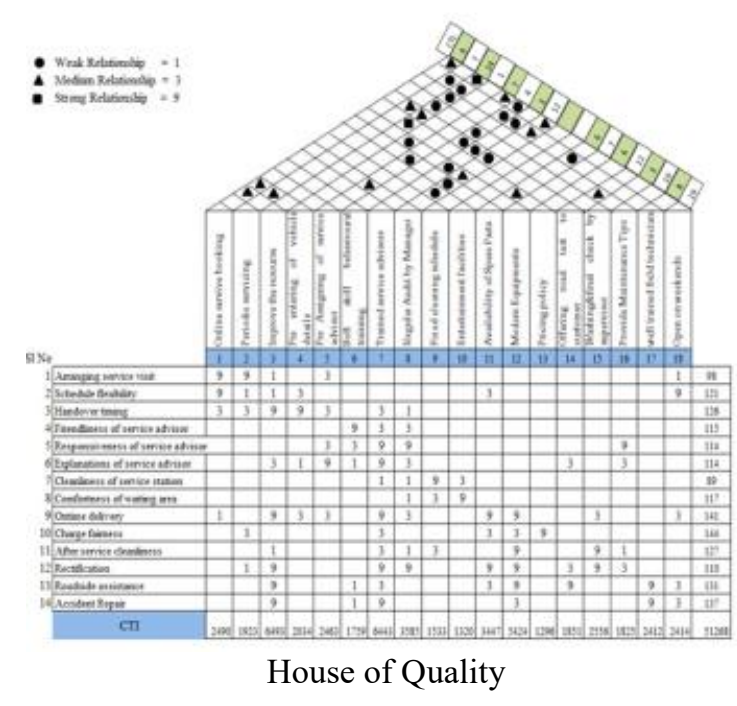

How much it takes to meet or exceed the customer's expectation is answered by evaluating all the information entered into the house of quality and selecting the target values.

\section{Degree Of Difficulty}

Many users of the house of quality add the degree of technical difficulty for implementing each technical descriptor. The scale range from I (very low difficult] to 5 (very high difficult). The degree of technical difficulty, when used, helps to evaluate the ability to implement certain quality improvement (Bestertield, 2006).

Customer Technical Interactive score $=\Sigma$ (Relationship values bet and technical languages) * (Expected value of customer voice).

E.g.: Customer Technical Interactive score for "Availability of spare parts" $=(3 * 131)+(9 * 121)+(3 * 154)+(9 * 120)+$ $(3 * 111)=3357$

\section{Percentage normalized value of customers}

technical interactive score

\section{$=\frac{\text { Customer Technical Interactive score }}{\text { Sum of Customer Technical Interactive score }} * 100$}

E.g.: Percentage normalized value of customers Technical interactive score of availability of spare parts $=(3357 /$ $51268)^{*} 100=6.547$

\section{Percentage normalized value of correlated \\ Weightage $=$ \\ Correlated weightage of Technical language Sum of correlated weightage $* 100$}

E.g.: Percentage normalized correlated weight age against technical parameter "Availability of spare parts" $=(4 / 136) *$ $100=2.941$

\footnotetext{
Priority value $=$ (Percentage normalized value of customers Techr + (Percentage normalized correlated weightage)
} 


\section{International Journal of Science and Research (IJSR) \\ ISSN (Online): 2319-7064}

Index Copernicus Value (2013): 6.14 | Impact Factor (2014): 5.611

E.g.: Priority value of "Availability of spare parts" $=6.547+$ $2.941=9.488$

\section{Summary of the Result}

After filtering out the specific customer needs, HOQ frame work was used to map the design requirements. In a technical importance point of view, the first three design requirements are-"recruiting skilled employees", "technical training to workers" and "availability of spares". The degree of technical difficulty and technical importance level were also documented. The studied proposed methodology could make a valuable contribution by enhancing the understanding of the perceived service quality of motor cycle service firm.

\section{Conclusion}

The major contribution to this work is the adoption of a more comprehensive approach to investigating the service quality items tool QFD. QFD does not design to replace the existing organization design process by any means, but rather support the organization 's design process. Cutting service time is also very beneficial to the companies.

QFD chart is a result of the original customer requirements that are not lost misinterpretations or lack of communication. QFD forces the entire organization to constantly be aware of the customer requirements. From a methodological perspective, it can be concluded that the ability of designing services upon customer satisfaction make this approach a powerful tool for service sectors. Most importantly, implementing QFD results in a satisfied customer.

\section{References}

[1] V R Pramod, S R Devadasan V P Jagathy Raj (2006) Customer voice adoption for Maintanance Quality Improvement through MQFD and its receptivity analysis, Int journal of Management practice, Vol.2 N0.2,pp.83-108.

[2] V R Pramod\& V P Jagadiraj(2006) Integrating TPM and QFD for improving quality maintenance Engg. Emerald Journal of Quality in Maintenance Engineering Vol.12-pp 150-171.

[3] Lokamy a Aand Khaura A (1995), "Quality function deployment: total quality management for new product design "International journal of Quality and reliability management, Vol 12 No.6 pp 7384.

[4] Chao, L P and Ishii K (2004) "Project quality function deployment “, International journal of quality \& Reliability Management" V R Pramod, S R Devadasan V P Jagathy Raj (2006ol 21 No.9 pp 933-58.

[5] Da Silva, F..L.R and dedni FG (2004) "Combined application of QFD and other tools in the product design process" ,International Journal of Quality \& Reliability Management, Vol 21. No.2, pp231-52

[6] C RKothari, (2003) Research Methodology, PHI Learning, New Delhi

[7] Baba MdDeros\&Ahmed Husain Said (2009) Application of QFD to study Critical Service Quality
Characteristics and performance measures European Journal of Scientific ResearchVol.33-pp398-410

[8] Baba MdDeros\&Ahmed Husain Said (2009) Application of QFD to study Critical Service Quality Characteristics and performance measures European Journal of Scientific ResearchVol.33-pp398-410

[9] Bridogan,Cigdem and ZuhailCilingir (2009), An application of integrating SERVQAL and KAnos model into QFD for logistics services, Vol 21 Iss: 1,pp.106126

[10] Charls Berger , Rchter.R and Robert Blauth(1999), Kanos methods for understanding customer defined quality, The centre for Quality Management Journal,Vol.2 No.4,pp.3-36

[11] Gupta A and Chen (1995), service quality : implications for management development, International Journal of Quality Reliability Management, Vol.44,pp 104-110

[12] Service Sector, Economic survey 2010-2011, Govt. of India pp, 237-257 58

[13]Teas. K R (1993)," Expectations, performance evaluation, and consumeres perception of quality" Journal of Marketing, pp.18-34. 